\title{
HEIDELBERG AND HUSSITISM. PROFESSORS AS ENVOYS, EXPERTS AND INQUISITORS
}

\author{
HEIKE HAWICKS
}

Against the background of the reform councils of the 15th century, the role of professors from the University of Heidelberg as envoys and their relationship to the Hussite question will be examined. They also acted as anti-Hussite experts, authors of treatises, polemical writings and sermons. When inquisition trials took place in the area of influence of the Electoral Palatinate during the Hussite Wars, professors, council envoys and scholars were also involved, so that a core of anti-Hussite advisors around Elector Palatine Louis III becomes recognizable.

Keywords: Hussitism - University of Heidelberg - University of Prague - Electoral Palatinate - Council of Pisa Council of Constance - Council of Basle - Elector Palatine Louis III - John of Frankfurt - Nicholas Magni de Jawor - Conrad Koler of Soest - Job Vener - Jerome of Prague - Jan Hus

DOI: $10.14712 / 23365730.2020 .30$

In view of the close personal ties between the universities of Heidelberg and Prague, even at the time of the former's foundation, it would seem appropriate during a conference on university professors at the venerable University of Prague to take a look at the role professors played in the period of Hussitism in Heidelberg, especially in the first quarter of the 15th century. The attitude of the Rhenish Palatine Counts and in particular of Louis III, who was Protector of the Council of Constance at King Sigismund's side, was essentially influenced by advisors recruited from among the professors of Heidelberg University. In this respect, it makes sense to focus on the envoys, starting with the councils of the 15 th century. ${ }^{1}$ In addition, professors will be focussed upon as anti-Hussite experts, as well as authors of treatises, polemical writings and sermons. As a result of Hussite anxiety, some inquisition trials began in 1421 in the area of influence of the Electoral Palatinate, in which professors, council envoys and authors of polemical writings were also involved. We will examine whether a core of anti-Hussite agitation can be identified in each of the persons involved and whether focal points of their actions can be determined. In this respect, this approach investigates the extent to which it was possible for individual personalities to influence the politics of the Palatine Count in detail, or whether the general Hussite anxiety equally affected the professors.

1 Cf. as an overview with literature Heribert Müller, Universitäten und Gelehrte auf den Konzilien von Pisa (1409), Konstanz (1414-1418) und Basel (1431-1449), in: Rainer Christoph Schwinges (ed.), Universitäten, Religion und Kirchen, Basel 2011 (Veröffentlichungen der Gesellschaft für Universitäts- und Wissenschaftsgeschichte 11), pp. 109-144. 


\section{Professors as envoys}

When looking at Heidelberg University embassies in the first quarter of the 15th century, one initially encounters the prohibition of King Rupert in 1409, when he forbade members of the University of Heidelberg to visit the Council of Pisa, against which he also solemnly protested as an advocate of the Obedience to Rome shortly afterwards. ${ }^{2}$ In the end, he only sent a royal delegation. ${ }^{3}$ Among its members were Matthew of Kraków, a former member of the University of Prague, and Bishop Ulrich of Verden, the successor of Conrad of Soltau to this see, who had also come to Heidelberg from Prague at the time. In August King Rupert nominated another delegation, which can thus be assigned to the Synod of Cividale. ${ }^{4}$

In contrast, an official Heidelberg university delegation was sent to the Council of Constance under his successor Elector Palatine Louis III, but only relatively late on 23rd March 1416, about 17 months after the opening of the Council and almost one year after the burning of Jan Hus on 6th July 1415.5 In addition to the Rector Nicholas of Bettenberg (lawyer), Nicholas Magni de Jawor as theologian and dean of the Monastery of the Holy Ghost, John of Frankfurt (also doctor of theology), Henry of Gulpen (doctor of jurisprudence), Conrad Koler of Soest (sancte pagine professor), Reinbold Vener (licentiate of jurisprudence) and Gerhard Brant (licentiate of medicine and bachelor of theology) were members of the group ${ }^{6}$ (cf. Fig. 1). Nicholas Magni de Jawor had moved from Prague to Heidelberg in 1402.

2 Eduard Winkelmann (ed.), Urkundenbuch der Universität Heidelberg, II, Regesten, Heidelberg 1886, n. 169 and 171.

3 The delegation included Archbishop John of Riga, Bishop Ulrich of Verden, Bishop Matthew of Worms/ Kraków, the Protonotary John of Weinheim and Magister Conrad of Soest as well as Reinbold Vener as a witness at the royal appeal against the Council of Pisa on 19th April 1409; Julius WeIzsäcKer (ed.), Deutsche Reichstagsakten (RTA), VI, Deutsche Reichstagsakten unter König Ruprecht, Dritte Abtheilung 1406-1410, Gotha 1888, n. 292-294 and 297; q.v. Karl Rudolf KöTzschкE, Ruprecht von der Pfalz und das Konzil von Pisa, Jena 1889, pp. 55f.; Remigius BÄumer, Konrad von Soest und seine Konzilsappelation 1409 in Pisa, in: idem (ed.), Das Konstanzer Konzil, Darmstadt 1977, pp. 96-118, here pp. 101f.; Aloys ScHMIDT - Hermann HeIMPEL (eds.), Winand von Steeg (1371-1452), ein mittelrheinischer Gelehrter und Künstler und die Bilderhandschrift über Zollfreiheit des Bacharacher Pfarrvereins auf dem Rhein aus dem Jahre 1426 (Handschrift 12 des Bayerischen Geheimen Hausarchivs zu München), München 1977 (Abhandlungen. Bayerische Akademie der Wissenschaften, phil.-hist. Klasse / NF 81), p. 122; Winfried EBERHARD, Konrad Koler von Soest, Konzilstheologe und königlicher Rat, in: Heinz-Dieter Heimann (ed.), Von Soest - Aus Westfalen. Wege und Wirken abgewanderter Westfalen im späten Mittelalter und der frühen Neuzeit, Paderborn 1986, pp. 93-123, here p. 101, n. 30 and p. 114; Dagmar DRÜLl, Heidelberger Gelehrtenlexikon 1386-1651, Berlin - Heidelberg 2002, p. 468; Matthias Nuding, Matthäus von Krakau, Theologe, Politiker, Kirchenreformer in Krakau, Prag und Heidelberg zur Zeit des Großen Abendländischen Schismas, Tübingen 2007 (Spätmittelalter und Reformation, Neue Reihe 38), pp. $206 f$.

4 The members of this delegation were John of Egloffstein, Bishop of Würzburg, Matthew of Kraków, Bishop of Worms, Bishop Ulrich of Verden, Abbot Albert of Maulbronn, the Dean of Würzburg Otto of Milcz, Nikolaus Magni de Jawor and Conrad Koler of Soest; RTA 6, n. 306.

5 Cf. Lorenz Dax, Die Universitäten und die Konzilien von Pisa und Konstanz, Freiburg im Breisgau 1910, pp. 34-36, and as an overview Ansgar Frenken, Gelehrte auf dem Konzil. Fallstudien zur Bedeutung und Wirksamkeit der Universitätsangehörigen auf dem Konstanzer Konzil, in: Heribert Müller - Johannes Helmrath (eds.), Die Konzilien von Pisa (1409), Konstanz (1414-1418) und Basel (1431-1449): Institution und Personen, Ostfildern 2007, pp. 107-147.

6 University Archives of Heidelberg (UAH), RA 653, fol. 109v; Jürgen MiETHKE (ed.), Die Rektorbücher der Universität Heidelberg, I, 1386-1410, bearb. von Heiner LuTZMANN - Hermann WEISERT, Heidelberg 1986-1999 (Libri actorum Universitatis Heidelbergensis, Series A, Reihe A I.1-3), n. 471; cf. summarising the course and background of the Constance Trials against the Hussites Jürgen Miethke, Die Prozesse in Konstanz gegen Jan Hus und Hieronymus von Prag - ein Konflikt unter Kirchenreformern?, in: František Šmahel (ed.), 
The rather late convocation of the Heidelberg University delegation had political reasons, because it followed the conclusion and invocation of the Treaty of Narbonne by the synodal members in February 1416, in which the antipope Benedict XIII was robbed of his followers. ${ }^{7}$ The time was ripe for the University of Heidelberg to send a delegation only after the deposition of John XXIII on 31st May 1415, the subsequent convening of the Council by Gregory XII and his abdication on 4th July $1415,{ }^{8}$ as well as the disempowerment of Benedict XIII in the Treaty of Narbonne of December 1415 and his summoning in February 1416.

Elector Palatine Louis III had stayed as council protector at Sigismund's side in Constance from 1415 and had come with an entourage of several persons. The Chronicle of Ulrich Richental (Aulendorf manuscript, cf. Fig. 2) and the register of the Austrian Duke Ernest the Iron (son of Leopold III), which is structured according to estates, contain divergent and contradictory information about the accompaniment of Louis in $1415 .{ }^{9}$ Other participants are also mentioned in the report: Besides the Heidelberg professor Nicholas Burgmann (decanus Spirensis decretorum doctor), who had studied in Prague at the time of Conrad of Soltau, these are the brother of the delegation member Reinbold Vener, Job Vener (magister arcium Job Vener doctor utriusque, cf. Fig. 3), as well as his familiaris Paul Hettler. ${ }^{10}$ In this respect, the names of the latter can better be attributed to Louis's entourage, so that professors in Constance attended without being part of the official university delegation. This also applies to Conrad Koler of Soest, nominated for the delegation, who must have been in Constance earlier, because he left for Perpignan immediately after the integration of the Gregorians into the Council together with King Sigismund for the negotiations with the Obedience of Benedict XIII. ${ }^{11}$

Job Vener in particular played an important role at the Council of Constance. Louis III's companion was one of the few to combine the dignity of a doctorate in both divisions of jurisprudence, a rarity north of the Alps in his day - he was already at the time of King Rupert one of his most important diplomats and councillors and headed the court lawyers. ${ }^{12}$ As early as the beginning of 1405 he had asked the University of Heidelberg to release him from his oath, since his business at the royal court would be very demanding on him, but the university had rejected his request. ${ }^{13}$ Accordingly, it is consistent that he - although a professor - is not to be found in the university delegation. He probably did not give any

Häresie und vorzeitige Reformation im Spätmittelalter, München 1998 (Schriften des Historischen Kollegs 39), pp. 147-167.

7 Heike Hawicks, Universität und landesherrliche Politik: Gründung, Fundierung und Gestaltungskraft der Universität Heidelberg zur Zeit des Abendländischen Schismas und der Konzilien, in: Martin Kintzinger Wolfgang Eric Wagner (eds.), Hochschule und Politik - Politisierung der Universitäten (Veröffentlichungen der Gesellschaft für Universitäts- und Wissenschaftsgeschichte) [in print].

8 Cf. W. Eberhard, Konrad Koler von Soest, p. 117.

9 Cf. Hermann Heimpel, Die Vener von Gmünd und Straßburg 1162-1447. Studien und Texte zur Geschichte einer Familie sowie des gelehrten Beamtentums in der Zeit der abendländischen Kirchenspaltung und der Konzilien von Pisa, Konstanz und Basel, 3 Bände, Göttingen 1982 (Veröffentlichungen des Max-Planck-Instituts für Geschichte 52), 1, p. 329.

10 Cf. ibid., pp. 330 and 360.

11 W. EBerhard, Konrad Koler von Soest, p. 117.

12 Comment on the protonotary in Christoph Freiherr von BRANDEnSTEIn, Urkundenwesen und Kanzlei, Rat und Regierungssystem des Pfälzer Kurfürsten Ludwig III. (1410-1436), Göttingen 1983 (Veröffentlichungen des Max-Planck Instituts für Geschichte 71), and H. HeIMPEL, Die Vener, I, p. 341 with n. 56.

13 E. Winkelmann, Urkundenbuch, II, Regesten, n. 149. 
lectures, but received an annual salary from the university until 1406, i.e. after his request for release, and was entitled to live in a house in Heidelberg until he left, ${ }^{14}$ which he apparently did in about 1423 .

His case shows that as a professor one did not necessarily require regular work for a university post - John of Frankfurt did not hold any theological lectures and was a "supernumerary" professor at the Faculty of Theology until his death. ${ }^{15}$ Job Vener carried out on behalf of the Elector Palatine more important activities in his service, but is called utriusque iuris professor. ${ }^{16}$ During the Council of Constance, he even became the papal candidate of the German nation and was proposed four times in two electoral ballots on 10th and 11th November 1417 . Thus, he was the only one to receive the two-thirds majority - questions of rank weighting, however, prevented Job from further success, although he would have been a candidate "after the heart" of the German nation. ${ }^{17}$

His older brother Reinbold Vener, however, was a member of the official university delegation and had already been King Rupert's envoy to Pisa in 1409. Reinbold was first a Magister of Arts, from the end of 1411 a licentiate of Canon Law and 1418/19, after the Council of Constance, Rector of the University of Heidelberg. He later took part in the Council of Basle, but as a representative of the city of Strasbourg, where he was in the service of the cathedral chapter. ${ }^{18}$

But we now come to other celebrities of the delegation. Conrad Koler of Soest had already been the spiritual head of the royal delegation to the Council of Pisa in $1409,{ }^{19}$ in which he had participated, as mentioned above, together with Nicholas Magni de Jawor and Reinbold Vener as well as Matthew of Kraków. ${ }^{20} \mathrm{He}$ is a good example of one of the professors considered to be "delegates in multiple functions", 21 since Louis sent him from

14 D. DRÜLL, Heidelberger Gelehrtenlexikon, pp. 257.

15 Marie-Luise Bulst-Thiele, Johannes von Frankfurt $(\dagger$ 1440). Professor der Theologie an der Universität Heidelberg, Rat des Pfalzgrafen und Kurfürsten Ludwigs III., in: Wilhelm Doerr (ed.), Semper Apertus. Sechshundert Jahre Ruprecht-Karls-Universität Heidelberg 1386-1986, I, Mittelalter und Frühe Neuzeit 1386-1803, Berlin - Heidelberg - New York - Tokyo 1985, pp. 136-161, here p. 136; D. DrüLL, Heidelberger Gelehrtenlexikon, p. 285.

16 UAH, RA 654, fol. 16r; Jürgen Miethкe (ed.), Die Rektorbücher der Universität Heidelberg, II, 1421-1451, ed. by Heiner LutzMAnN, Heidelberg 2001-2003 (Libri actorum Universitatis Heidelbergensis, Series A, Reihe A II.1-2), p. 39; cf. D. Drüll, Heidelberger Gelehrtenlexikon, p. 257; A. SchmidT - H. HeImpel, Winand von Steeg, p. 122.

17 H. Heimpel, Die Vener, I, p. 376; Heike Hawicks - Ingo Runde (eds.), Päpste-Kurfürsten - Professoren - Reformatoren. Heidelberg und der Heilige Stuhl von den Reformkonzilien des Mittelalters bis zur Reformation. Katalog zur Ausstellung im Kurpfälzischen Museum vom 21. Mai bis 22. Oktober 2017, hg. vom Universitätsarchiv Heidelberg sowie vom Historischen Verein zur Förderung der internationalen Calvinismusforschung e.V. und vom Kurpfälzischen Museum Heidelberg, Heidelberg - Neustadt an der Weinstraße - Ubstadt-Weiher Basel 2017, n. 3.08, p. 47 (online-Version: <https://www.uni-heidelberg.de/md/uniarchiv/heidelberg_und_der heilige stuhl web.pdf>, accessed 26.07.2019); Heike Hawicks - Ingo Runde, Heidelberg and the Holy See $\bar{f}$ rom the Late Medieval Reform Councils to the Reformation in the Electoral Palatinate, in: Simona Negruzzo (ed.), 1517. Le università e la Riforma protestante. Studi e ricerche nel quinto anniversario delle tesi luterane, Bologna 2018, pp. 35-56, here p. 43.

18 D. DRÜLl, Heidelberger Gelehrtenlexikon, p. 468.

19 Ch. v. Brandenstein, Urkundenwesen, p. 375; Peter Moraw, Beamtentum und Rat König Ruprechts, in: Zeitschrift für die Geschichte des Oberrheins 116 / NF 77, 1968, pp. 59-126, here p. 116; W. EBERHARD, Konrad Koler von Soest, p. 100; D. DRÜLL, Heidelberger Gelehrtenlexikon, p. 100.

20 Cf. M. Nuding, Matthäus von Krakau, pp. 203-208.

21 Jürgen Miethke, Die Universitäten und das Basler Konzil, in: Heribert Müller (ed.), Das Ende des konziliaren Zeitalters (1440-1450). Versuch einer Bilanz, München 2012, pp. 197-232, here p. 218. 
Constance to negotiate with (Anti)Pope Benedict in Spain, where the resignation of the latter could not be achieved, but at least his followers were convinced, thus enabling the Treaty of Narbonne to be signed.

Table 1. Participation of professors at the major councils Only those professors are listed in the table who have also appeared in other contexts of Hussitism (in brackets: participation outside the official university delegation).

\begin{tabular}{|l|c|c|c|c|}
\hline Professors & $\begin{array}{c}\text { Pisa/Cividale } \\
(1409)\end{array}$ & $\begin{array}{c}\text { Constance } \\
(1414-1418)\end{array}$ & $\begin{array}{c}\text { Pavia/Siena } \\
(1423 / 24)\end{array}$ & $\begin{array}{c}\text { Basle } \\
(1431-1449)\end{array}$ \\
\hline Conrad Koler of Soest & $\mathrm{X}$ & $\mathrm{X}$ & $\mathrm{X}$ & $\mathrm{X}$ \\
\hline Nicholas Magni de Jawor & $\mathrm{X}$ & $\mathrm{X}$ & - & $\mathrm{X}$ \\
\hline Gerhard Brant of Deventer & - & $\mathrm{X}$ & $\mathrm{X}$ & $\mathrm{X}$ \\
\hline Job Vener & - & $(\mathrm{X})$ & - & $(\mathrm{X})$ \\
\hline John of Frankfurt & - & $\mathrm{X}$ & - & - \\
\hline Otto de Lapide & - & - & - & $\mathrm{X}$ \\
\hline Nicholas Burgmann & - & $(\mathrm{X})$ & - & - \\
\hline
\end{tabular}

In 1423 Conrad Koler was again sent to the Council of Pavia ${ }^{22}$ together with Gerhard Brant. There he was president of the German nation and as such signed the controversial transfer of the Council to Siena. ${ }^{23} \mathrm{He}$ also took part in the Council of Basle - but not as a Palatine envoy - where he met his former Heidelberg colleagues Nicholas Magni de Jawor, Gerhard Brant and Otto de Lapide as Louis's envoys, all on a mission for reconciliation with Bohemia. ${ }^{24}$ In 1428 he became Bishop of Regensburg.

In 1402, when Jan Hus was magister artium and began preaching in Prague, Nicholas Magni de Jawor already held an appointment as professor in Heidelberg, ${ }^{25}$ to where his teachers Matthew of Kraków and Conrad of Soltau had also moved. ${ }^{26}$ He could possibly have been one of the professors who knew Jerome of Prague from his time as a student in Prague. ${ }^{27}$

With John of Frankfurt a vehement opponent of Hussitism and especially of Jerome of Prague finally entered the Constance stage. For the latter had already been expelled from the art faculty of Heidelberg in $1406,{ }^{28}$ shortly after his arrival there, because in his disputation

22 E. Winkelmann, Urkundenbuch, II, Regesten, n. 220.

23 W. Eberhard, Konrad Koler von Soest, p. 118; Walter Brandmüller, Das Konzil von Pavia-Siena 1423-1424, I, Darstellung, Münster 1968 (Vorreformationsgeschichtliche Forschungen 16), p. 99 with n. 20.

24 E. Winkelmann, Urkundenbuch, II, Regesten, n. 220, 261 and 263ff; cf. to Brant (with contemporary illustration) Rudolf HaAs, Acht Heidelberger Professorenbilder aus dem Jahr 1426, in: Ruperto Carola 20, Band 43/44, 1968, pp. 36-42, here p. 39.

25 Cf. Pavel Soukup, Die Rolle der Prager Universitätsmigration in der antihussitischen Polemik 1409-1436, in: Acta Universitatis Carolinae - Historia Universitatis Carolinae Pragensis 49/2, 2009, pp. 71-80, here p. 74; IdEm, Jan Hus, Stuttgart 2014, p. 24f.; Franz MAchilek, Jan Hus (um 1372-1415). Prediger, Theologe, Reformator, Münster 2019, p. 65; Rainer Christoph Schwinges, Der Student in der Universität, in: Walter Rüegg (ed.), Geschichte der Universität in Europa, I, München 1993, pp. 181-223, here p. 202.

26 Cf. D. DrüLl, Heidelberger Gelehrtenlexikon, pp. 100f., $378 \mathrm{f}$.

27 About the times in Prague ibid., p. 408.

28 Dorothea Walz, Das erste Jahrhundert der Universität Heidelberg nach Marsilius von Inghen, in: Dorothea Walz - Reinhard Düchting (eds.), Marsilius von Inghen. Gedenkschrift 1499 zum einhundertsten Todestag des Gründungsrektors der Universität Heidelberg, Heidelberg 2008 (Lateinische Literatur im deutschen Südwesten 1), pp. 25-35, here pp. $26 f$. 
on the topic Utrum veritas generalis sit significanda he had expressed himself 'arrogantly, presumptuously, ruggedly and shamefully' (arroganter, presumptuose, importune et contumeliose) about living and deceased doctors and masters. ${ }^{29}$ The artium magister and later professor of theology John of Frankfurt then felt compelled to write a public statement against him and his views. ${ }^{30}$

With regard to the Council of Constance, these preceding biographies may well be relevant: The execution of Jan Hus with the participation of the Elector Palatine Louis caused ripples, but the case of Jerome of Prague may have attracted even more interest, at least among the Heidelberg professors. After all, even in the 1410 Vienna trial professors from Heidelberg had voiced their opposition to him. ${ }^{31}$ The fact that these two - Nicholas Magni de Jawor and John of Frankfurt - were now part of the university delegation, which was called just in those weeks when, after his revocation, 'the German as well as the Bohemian opponents of Jerome could not be brought to rest', ${ }^{32}$ may be telling.

However, the records do not allow any concrete conclusion to be drawn as to whether the Heidelberg professors contributed to condemning him, but his last hearing on 26th May 1416 was 'about theses which the Master had defended at various universities' - unfortunately, however, the minutes report nothing about their content. ${ }^{33}$ But even before the Heidelberg University mission had arrived in Constance, a Heidelberg voice had risen against him, accusing him of Trinitarian errors ${ }^{34}$ - whether this was one of Louis's companions must ultimately remain unclear, although this assumption has a certain plausibility. Conrad Koler of Soest must also have been in Constance before the official university mission, otherwise he would not have been able to leave for Spain together with King Sigismund.

Elector Palatine Louis III did not take part in the burning of Jerome on 30th May - even if the illustrations in the Richental Chronicle would have us believe it (Fig. 4). He was in Heidelberg at that time, where the conspiracy for the liberation of Baldassare Cossa, the deposed Antipope John XXIII, who was imprisoned at the castle there, made his personal presence necessary, and did not arrive in Constance again until 3rd June. ${ }^{35}$

Some of the Heidelberg professors who are presented here wrote anti-Hussite literature, which will be discussed below.

29 UAH, H-IV-101/1, fol. 28r; UAH, RA 653, fol. 91v, printed in: Die Rektorbücher der Universität Heidelberg, I, n. 427, pp. 413f.; cf. D. Walz, Das erste Jahrhundert, pp. 25-27.

30 Johannes von Frankfurt, Videte, ne qui vos decipiat. Angriffsrede gegen die Quaestio Utrum veritas generalis sit significanda des Hieronymus von Prag, ed. Angelika HäsE, in: Dorothea Walz (ed.), Johannes von Frankfurt, Zwölf Werke des Heidelberger Theologen und Inquisitors, Heidelberg 2000, pp. 99-100.

31 Alfred A. Strnad, Die Zeugen im Wiener Prozeß gegen Hieronymus von Prag. Prosopographische Anmerkungen zu einem Inquisitionsverfahren im Vorfelde des Hussitismus, in: Jaroslav Pánek - Miloslav Polívka - Noemi Rejchrtová (eds.), Husitství, reformace, renesance. Sborník k 60. narozeninám Františka Šmahela [Hussitism - Reformation - Renaissance. Volume to the $60^{\text {th }}$ Birthday of František Šmahel], I-III, Prag 1994, I, pp. 331-368, here pp. 342-345.

32 Walter Brandmüller, Das Konzil von Konstanz 1414-1418, II, Bis zum Konzilsende, Paderborn - München Wien - Zürich 1997 (Konzilsgeschichte, Reihe A: Darstellungen), p. 125; cf. František ŠMAHEL, Leben und Werk des Magisters Hieronymus von Prag. Forschung ohne Probleme und Perspektiven?, in: Historica 13, 1966, pp. 81-111; most recently Idem and Gabriel Silagi (eds.), Magistri Hieronymi de Praga, Quaestiones, Polemica, Epistulae (Corpus Christianorum, Continuatio mediaevalis 222), Turnhout 2010, pp. XI-CXXVIII.

33 W. Brandmüller, Das Konzil von Konstanz, p. 132.

34 Cf. ibid., p. 120.

35 Cf. Wilhelm EBerhard, Ludwig III. Kurfürst von der Pfalz und das Reich 1410-1427. Ein Beitrag zur deutschen Reichsgeschichte unter König Siegmund, Gießen 1896, pp. 72 and 66; H. HeImPeL, Die Vener, I, p. 352 with n. 105; H. Hawicks - I. RundE, Heidelberg and the Holy See, pp. 42-45. 


\section{Professors as experts}

As mentioned, John of Frankfurt had already come to the fore in 1406, especially with his proposition against Jerome, Videte, ne quis vos decipiat, ${ }^{36}$ and can therefore be regarded as his most decisive opponent, as shown above.

Table 2. Writings of Heidelberg scholars against Hussites

\begin{tabular}{|c|c|c|c|c|}
\hline \multirow[t]{2}{*}{$\begin{array}{l}1406 \\
\text { Proposition against } \\
\text { Jerome: Videte, ne } \\
\text { quis vos decipiat }\end{array}$} & $\begin{array}{l}1418 / 19 \\
\text { Adamas } \\
\text { colluctancium } \\
\text { aquilarum } \\
\text { (Diamond of the } \\
\text { Fighting Eagles) }\end{array}$ & $\begin{array}{l}1421 \\
\text { Tracts against the } \\
\text { Hussites }\end{array}$ & $\begin{array}{l}1425 \\
\text { Quaestio de } \\
\text { haereticis }\end{array}$ & $\begin{array}{l}\text { 1430/31 } \\
\text { Responde stulto } \\
\text { (bzw. scriptum } \\
\text { contra epistolam } \\
\text { perfidiae } \\
\text { Hussitarum) }\end{array}$ \\
\hline & & & $\begin{array}{l}\text { Nicholas Magni de } \\
\text { Jawor }\end{array}$ & $\begin{array}{l}\text { Nicholas Magni de } \\
\text { Jawor (1430) }\end{array}$ \\
\hline \multirow[t]{4}{*}{ John of Frankfurt } & & $\begin{array}{l}\text { John of Frankfurt } \\
\text { (as well as later } \\
\text { sermons in } \\
\text { Heidelberg and } \\
\text { Lauda) }\end{array}$ & & \\
\hline & & $\begin{array}{l}\text { Conrad Koler of } \\
\text { Soest (with sermon } \\
\text { at Saaz) }\end{array}$ & & \\
\hline & Winand of Steeg & Job Vener & & John Wenk (1431) \\
\hline & & $\begin{array}{l}\text { John Plate (text } \\
\text { not extant and not } \\
\text { dateable) }\end{array}$ & & \\
\hline
\end{tabular}

The expert opinions, written by professors from the University of Heidelberg during the second Hussite Crusade, so to speak in the middle of the turmoil of fighting outside Saaz in 1421 , also play an important role. These were the statements of the scholars accompanying Louis, i.e. John of Frankfurt (Contra Hussitas, a refutation of the Four Prague Articles for Elector Palatine Louis III) ${ }^{37}$ and Conrad Koler of Soest (Tractatus contra Hussitas) ${ }^{38}$ as well as most probably also of Job Vener, who had been active at the Council and who often cooperated with Conrad Koler of Soest during those years. ${ }^{39}$ Of his three Hussite writings

36 Johannes von Frankfurt, Videte (ed. A. HäsE); cf. Ingo Runde, Statuten und Reformen der Universität Heidelberg im Kontext von Politik, Religion und Wissenschaft - von der Gründungsphase bis zum Ausgang des 16. Jahrhunderts, in: Benjamin Müsegades - Ingo Runde (eds.), Universitäten und ihr Umfeld. Südwesten und Reich in Mittelalter und Früher Neuzeit. Beiträge zur Tagung im Universitätsarchiv Heidelberg am 6. und 7. Oktober 2016, Heidelberg 2019 (Heidelberger Schriften zur Universitätsgeschichte 7), pp. 35-72, here pp. $46 f$.

37 Johannes von Frankfurt, Contra Hussitas. Widerlegung der Vier Prager Artikel für Kurfürst Ludwig III. von der Pfalz (Saaz, 1421), ed. Brigitta CALlsen - Angelika Häse, in: Johannes von Frankfurt, Zwölf Werke, pp. 101-125.

38 Bavarian State Library Munich, Clm 5411; cf. W. Eberhard, Konrad Koler von Soest, p. 118 with n. 115 ; P. Soukup, Die Rolle, p. 75 with n. 28, in which an edition of the Koler-writing is announced.

39 Cf. Hermann Heimpel, Konrad von Soest und Job Vener, Verfasser und Bearbeiter der Heidelberger Postillen (Glossen), zu der Berufung des Konzils von Pisa. Zum Regierungsstil am Hof König Ruprechts von der Pfalz, in: Westfalen 51, 1973, pp. 115-124, here pp. 119f. 
from the year $1421,{ }^{40}$ the most interesting in this context is the Exhortatio quedam contra Hussitas, which, contrary to its Latin title, has been handed down in German. ${ }^{41}$

In addition to his Tractatus contra Hussitas on 16th September 1421 in campo bohemico prope Sacz (i.e. in the camp of Saaz), Conrad Koler also gave a speech against the Hussites, which is preserved in a manuscript in Vienna. ${ }^{42}$

G. Ritter has impressively described the circumstances of this Hussite crusade: "The Electors themselves went into the field, and the Palatine Count was accompanied by his court theologians. After slight initial successes, the company led to a protracted and ultimately futile siege of Saaz, one of the main Hussite strongholds. Here in the camp, one mile in front of the besieged city, Elector Palatine Louis III received those famous 'four articles' from a Bohemian envoy [...]. In the camp of the crusader army they found a very unfavourable reception. Louis handed them over to his court theologians [...], who immediately began the theological refutation". 43

John Plate, who had been acting as Professor of Theology since 1420 and was Rector of the University of Heidelberg in 1414, 1424-1425 and 1434, also wrote a treatise Contra Bohoemos, which cannot be dated any closer; ${ }^{44}$ he died in 1438 . Therefore, it is not possible to decide whether this treatise is also related to the campaign of 1421 .

John of Frankfurt, however, was later a dedicated opponent of the Hussites (cf. Fig. 5). On March 19th 1422, he preached his Collatio Fortis armatus at the Church of the Holy Spirit in Heidelberg in front of newly graduated licentiates of the Faculty of Arts and warned of the Bohemian danger. ${ }^{45}$ At the same time there were riots in Heidelberg which began in March, ${ }^{46}$ in the course of which the mood was directed against John of Frankfurt and the students, whereby certain sympathies for the Hussites became clear in the saying, daz sie lieber erslagen und doden wolden studenten und paffen, dan die hussen. ${ }^{47} \mathrm{He}$ also acted as a preacher or speaker in the inquisition trials carried out by him in the following years. ${ }^{48}$

40 Cf. the compilation at H. Heimpel, Die Vener, II, pp. 1141-1147, III, pp. 1338-1365 (text).

41 H. Heimpel, Die Vener, III, pp. 1338-1350.

42 Austrian National Library (Wiener Hofbibliothek), Cod. 2415, fol. 77-80; cf. Adolph Franz, Der Magister Nikolaus Magni de Jawor. Ein Beitrag zur Literatur- und Gelehrtengeschichte des 14. und 15. Jahrhunderts, Freiburg im Breisgau 1898, p. 84, n. 2; cf. Winfried EBerhard, Art. Koler, Konrad, von Soest, in: Burghard Wachinger (ed.), Die Deutsche Literatur des Mittelalters. Verfasserlexikon, XI, Nachträge und Korrekturen, Berlin - New York 2004, col. 860-864, here col. 863; P. Soukup, Die Rolle, p. 75, n. 28.

43 Gerhard RitTer, Die Heidelberger Universität im Mittelalter (1386-1508). Ein Stück deutscher Geschichte, Heidelberg 1936 [Ndr. 1986], p. 358; H. Heimpel, Die Vener, I, p. 388.

$44 \mathrm{He}$ is mentioned in Johannes Trithemius, Catalogus Scriptorum Ecclesiasticorum, sive illustrium virorum cum appendice eorum qui nostro etiam seculo doctissimi claruere, 1462-1516, Coloniae: Petrus Quentell, 1531, fol. 137 (http://data.onb.ac.at/rep/10723500); cf. A. Franz, Der Magister, p. 89; but the text as such does not seem to have been preserved.

45 Johannes von Frankfurt, Fortis armatus custodit atrium suum (Lc 11,21). Reverendi patres, experiencia docet et ocularis monstrat inspectio - Collatio for the granting of the license to fifteen Baccalaurii of arts, $19^{\text {th }}$ March 1422; cf. Johannes von Frankfurt, Zwölf Werke, p. 270; Dorothea WaLz, Eine Sonntagspredigt des Heidelberger Theologen Johannes von Frankfurt $(†$ 1440), in: Ignacy Lewandowski - Andrzej Wójcik (eds.), Vetustatis amore et studio: Księga pamiątkowa ofiarowana Profesorowi Kazimierzowi Limanowi, Poznań 1995 (Seria Filologia klasyczna 19), pp. 41-48, here pp. 43 and 41 with n. 2.

46 Cf. M.-L. Bulst-Thiele, Johannes von Frankfurt, p. 142.

47 UAH, RA 654, fol. 16r; J. Miethke (ed.), Die Rektorbücher, II, p. 39; cf. Klaus-Peter Schroeder, „,Tod den Scholaren!“ - Studentenkriege, Revolten, Exzesse und Krawalle an der Heidelberger Universität von den Anfängen bis zum Ausgang des 20. Jahrhunderts, Heidelberg 2016 (Heidelberger Schriften zur Universitätsgeschichte 4), pp. 35-39.

48 Cf. M.-L. Bulst-Thiele, Johannes von Frankfurt, p. 141; A. Franz, Der Magister, p. 86. 
Influenced by the Council, Nicholas Magni de Jawor ${ }^{49}$ also produced writings such as the Quaestio de haereticis. ${ }^{50}$ At the end of the 19th century Adolph Franz expressed the suspicion that the Quaestio, which has been handed down together with comparable works by Gerhard Brant and John of Frankfurt, was written in connection with the Inquisition trial against John Drändorf in 1425. ${ }^{51}$ It is located in Codex 608 of the Bibliotheca Palatina in Rome. ${ }^{52}$ At the beginning of the 1930s Nicholas Magni, an expert on Heidelberg, responded to the Taborite manifestos of 1430/31 under the biblical verse Responde stulto,${ }^{53}$ which his student John Wenk entitled Scriptum [...] contra epistolam perfidiae Hussitarum. One year later, in 1431, Johannes Wenk joined Nikloaus Magni's endorsement of the Basle Council with the publication De utilitate sacrae concilii basileensi, in which he strongly condemned the error Bohemorum. ${ }^{54}$

Further anti-Hussite literature emerged in the run-up to the Hussite Wars. Among the writers of the Hussite Wars was the confidant of Louis III, Winand of Steeg, who called for the crusade with his writing Adamas colluctancium aquilarum (Diamond of the Fighting Eagles $)^{55}$ in 1418-1419. ${ }^{56}$ Winand of Steeg was a doctor of canon law and taught both in the law and theology faculties of the University of Würzburg, founded in 1402. Like the founder of that university, Bishop John of Egloffstein, he had studied in Heidelberg. An illustration from the richly illustrated manuscript shows the ecclesia malignanter repugnans. ${ }^{57}$

49 Cf. A. Franz, Der Magister, p. 117. Already during his time in Prague, Nicholas Magni de Jawor is ascribed the Dialogus super sacra communione; cf. Josef TřišKA, Literární činnost předhusitské univerzity [Literary activity of the pre-Hussite university], Praha 1967, pp. 121f.; Soukup, Die Rolle, p. $74=$ De tribus substantialibus 1400. However, this is a confusion of the author with the Dominican Nicolas Jacquier from Dijon, which was already disproved in 1913 by J. Volf, but is referred to as 'tache d'huile' in encyclopedic articles and specialist literature; cf. (with thanks for the reference to P. Soukup) Olivier MARIN, Les traités anti-hussites du dominicain Nicolas Jacquier († 1472). Une histoire du concile de Bâle et de sa postérité, Paris 2012 (Collection des Études Augustiniennes, Série Moyen Âge et Temps Modernes 49), p. 50.

50 Biblioteca Apostolica Vaticana, Pal. lat. 608 (tom. 2), fol. 245v-247v; cf. A. Franz, Der Magister, p. 116, n. 3; P. Soukup, Die Rolle, p. 76 with n. 39.

51 A. Franz, Der Magister, p. 117; Biblioteca Apostolica Vaticana, Pal. lat. 608 (tom. 2), fol. 245v-247v: Mag. Nicolai Magni de Jaulber (sic) (247v) quaestio utrum heretici asserentes clerum dominiis et possessionibus spoliandum sint iuxta ewangelium (sic) Xpi. Exterminandi et reuertentes aliquotiens ab heresi sint ab ecclesia totiens recipiendi (<https://digi.ub.uni-heidelberg.de/diglit/bav_pal_lat_608_2/0078>, accessed 26. 07. 2019).

52 Cf. A. Franz, Der Magister, p. 116; Biblioteca Apostolica Vaticana, Pal. lat. 608 (tom. 2), fol. 229r-240v: Mag. Gherhardi Brant de Dauentria quaestio ad quam respondit (236r) Mag. Iohannes Ernesti heydelbergensis anno 1436, 8 d. Marcii (<https://digi.ub.uni-heidelberg.de/diglit/bav_pal_lat_608_2/0045>, accessed 26. 07. 2019).

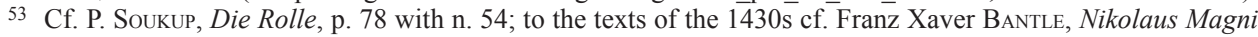
de Jawor und Johannes Wenk im Lichte des Codex Mc. 31 der Universitätsbibliothek Tübingen, in: Scholastik. Vierteljahresschrift für Theologie und Philosophie 38, 1963, pp. 536-574 and most recently Jiří PETRÁŠEK, ,,Meide die Häretiker. “ Die antihussitische Reaktion des Heidelberger Professors Nikolaus von Jauer (1355-1435) auf das taboritische Manifest aus dem Jahr 1430, Münster 2018 (Beiträge zur Geschichte der Philosophie und Theologie des Mittelalters, N.F. 82).

54 Cf. F. X. Bantle, Nikolaus Magni de Jawor, pp. 554ff., here esp. pp. 569f.

55 Cf. Agnes Graf, Winand von Steeg: Adamas colluctancium aquilarum. Ein Aufruf zum Kreuzzug gegen die Hussiten, Umění 40, 1992, pp. 344-351, and Barbara ОвRist, Das illustrierte ,Adamas colluctancium aquilarum " (1418-1419) von Winand von Steeg als Zeitdokument, Zeitschrift für Schweizerische Archäologie und Kustgeschichte 40, 1983, pp. 136-143.

56 Cf. P. Soukup, Die Rolle, p. 77 with n. 47.

57 A. Graf, Winand von Steeg, p. 345; B. OBrist, Das illustrierte „Adamas “, p. 141. 


\section{Professors as Inquisitors}

In addition to their role as envoys and experts, Heidelberg professors in particular also acted as inquisitors. If it is not possible in the case of Constance to identify any active participation in the trials against Jan Hus and Jerome from the records, a completely different development emerges in the period after the Constance Council. In the 1420s inquisition processes frequently took place within the sphere of influence of Count Palatine Louis.

\section{Table 3. Participation of professors in inquisition processes}

Only those professors are listed in the table who have also appeared in other contexts of Hussitism (participation without judicial function is indicated in brackets).

\begin{tabular}{|l|c|c|c|c|c|}
\hline Professors & $\begin{array}{c}\text { Dringenberger } \\
(1421)\end{array}$ & $\begin{array}{c}\text { Drändorf } \\
(1425)\end{array}$ & $\begin{array}{c}\text { Borchard } \\
(1425)\end{array}$ & $\begin{array}{c}\text { Turnau } \\
(1425)\end{array}$ & $\begin{array}{c}\text { Fuyger } \\
(1429)\end{array}$ \\
\hline John of Frankfurt & $\mathrm{X}$ & $\mathrm{X}$ & $\mathrm{X}$ & $\mathrm{X}$ & $\mathrm{X}$ \\
\hline Nicholas Magni de Jawor & $\mathrm{X}$ & $\mathrm{X}$ & $\mathrm{X}$ & - & \\
\hline Gerhard Brant of Deventer & - & - & $\mathrm{X}$ & $\mathrm{X}$ & \\
\hline Nicholas Burgmann & $\mathrm{X}$ & - & - & $\mathrm{X}$ & \\
\hline John Plate & - & $\mathrm{X}$ & $\mathrm{X}$ & - & \\
\hline Otto de Lapide & - & $\mathrm{X}$ & $\mathrm{X}$ & - & \\
\hline Job Vener & - & $(\mathrm{X})$ & - & $\mathrm{X}$ & \\
\hline Conrad Koler of Soest & $\mathrm{X}$ & - & - & - & \\
\hline
\end{tabular}

Immediately after his return from the defeat at Saaz described above, the heresy suspect Helwicus Dringenberger from Heiligenstadt was interrogated in 1421 in the bishop's court at Worms. In this case, in addition to the responsible Bishop of Worms, the following inquisitors were active as inquisitors: John Lagenator of Frankfurt, Nicholas Magni de Jawor and Conrad Koler of Soest from the university embassy of Constance, as well as from Louis's company Nicholas Burgmann, already mentioned above.

In the much more sensational trial against John Drändorf, who was later particularly highlighted as a Protestant martyr by Luther and Melanchthon in 1522, ${ }^{58}$ there are, among many other participants whose names are not listed here, members of the Constance delegation, John of Frankfurt and Nicholas Magni de Jawor. Louis's orator and protonotary Job Vener were present in a non-judicial function. The Drändorf trial was purposeful and impressive: after a short, only three-day trial, John Drändorf was burnt at the gates of Heidelberg on 17th February 1425.59

In the same year another lawsuit followed, which ended with a burning, namely that of Peter Turnau. If the canonically correct conduct of the trial, in contrast to the Drändorf trial,

58 H. Hawicks - I. Runde (eds.), Päpste - Kurfürsten - Professoren - Reformatoren, p. 49.

59 Hermann Heimpel (ed.), Drei Inquisitionsverfahren aus dem Jahre 1425: Akten der Prozesse gegen die deutschen Hussiten Johannes Drändorf und Peter Turnau sowie gegen Drändorfs Diener Martin Borchard, Göttingen 1969 (Veröffentlichungen des Max-Planck-Instituts für Geschichte 24), p. 18; Kurt-Victor SELGE, Heidelberger Ketzerprozesse in der Frühzeit der hussitischen Revolution, Zeitschrift für Kirchengeschichte 82, 1971, pp. 167-202, here p. 197. 
was adhered to here, a change could be ascertained in the course (above all in the duration) of the trial, but not in the result, which also led to the immolation of Turnau in Udenheim (today Philippsburg) on 11th June 1425. On the orders of the Bishop of Speyer, Job Vener was appointed as judge in charge of the proceedings, but apart from him from the Constance delegation only Nicholas Burgmann, also from the Speyer diocese, was nominated. The fact that the Speyer element predominates here is due to the area of competence in the nature of the matter. ${ }^{60}$ However, Job Vener, the professor of the two categories of jurisprudence, obviously had doubts, or his uncertainties about Turnau's skilful answers may have made the bishop dissatisfied - at any rate he sought support from the canonical magistri actu regentes in Heidelberg: and these were again two persons from the Constance university delegation: Gerhard Brant and John of Frankfurt (see above). Through the latter, who in the meantime (on June 2nd 1415, thus after the Drändorf trial) had been appointed by Pope Martin $\mathrm{V}$ as inquisitor for the archdioceses of Mainz and Trier, ${ }^{61}$ the inquisition was now taken in hand. His determination seems to have led to the abandonment of the advice of the lawyers and to the re-emergence of the theological aspects of the process. The result was thus foreseeable, the condemnation, so to speak, a settled matter. The texts and minutes of the two trials have been thoroughly reviewed by $\mathrm{H}$. Heimpel and offer an insight into the procedure and the conclusions that were drawn from the statements of the delinquents in this time of great Hussite anxiety - they offer as much material for a paper as the writings of Job Vener.

Later, John of Frankfurt conducted another heretical trial in Lauda near Würzburg, which also ended with the burning of the accused (John Fuyger) on July 4th $1429 .{ }^{62}$ One can thus peel out a firm core from the professorial circle of people who, personally, with expert opinions and active action, consistently took action against Hussite heretical ideas.

It may be significant that, after lengthy negotiations in 1436, the year of the death of Louis III, who had so resolutely fought against Hussitism, the Compacts of Basle could be proclaimed. ${ }^{63}$ As could be shown, only a few of his advisors had a share in this agreement reached at the Basle Council. A quarter of a century later, Pope Pius II rejected the Compacts and in 1478 Pope Sixtus IV even invalidated the decrees of the Council of Constance. The intensification of the Inquisition, ordered at the same time, was followed by renewed anti-Hussite statements by Heidelberg scholars and another Inquisition trial in $1479 .{ }^{64}$

Colour illustrations cf. pp. 285-290.

60 Ibid., p. 203.

61 Inquisitor heretice prauitatis also for the cities Mainz, Trier and Basle; cf. M.-L. Bulst-Thiele, Johannes von Frankfurt, p. 142.

62 Cf. G. RitTER, Die Heidelberger Universität, p. 360 with n. 3; H. HeImPEL (ed.), Drei Inquisitions-Verfahren, pp. 20 and 149f.; K.-V. SElge, Heidelberger Ketzerprozesse, pp. $193 \mathrm{f}$.

63 Cf. comprehensive František ŠMahel, Die Basler Kompaktaten mit den Hussiten (1436). Untersuchung und Edition, Wiesbaden 2019 (Monumenta Germaniae Historica - Studien und Texte 65).

64 Cf. G. RitTER, Die Heidelberger Universität, p. 361. 


\title{
Acknowledgements:
}

I would like to thank Peter Bews ( $\dagger$ ) from the English Department of the University of Heidelberg and Dr. Clive Bridger (Xanten) for the competent review of the English translation.

\author{
HEIKE HAWICKS
}

\section{HEIDELBERG UND DER HUSSITISMUS. PROFESSOREN ALS GESANDTE, GUTACHTER UND INQUISITOREN}

\section{ZUSAMMENFASSUNG}

Eine zentrale Figur bei allen antihussitischen Aktivitäten im Umkreis von Kurfürst Ludwig III. ist Johannes von Frankfurt: Er war an allen Ketzerprozessen maßgeblich beteiligt, hatte im Feldlager Gutachten gegen die Hussiten verfasst und war in der Konstanzer Delegation vertreten. Er taucht aber auf keinem weiteren Konzil mehr auf, sondern betätigte sich vornehmlich als aktiver und unerbittlicher Inquisitor. Demgegenüber nahmen Nikolaus Magni de Jawor, Gerhard Brant und insbesondere Konrad Koler von Soest an Konzilien teil. Letzterer war tatsächlich bei allen Konzilien vertreten und auf dem Basler Konzil (als Regensburger Bischof) sogar einer der drei Vorsitzenden der Glaubenskommission, die mit den Hussiten Verhandlungen führte. Er war es auch, der deren Delegation 1432 nach Basel geleitete. Sein (früherer) Heidelberger Kollege Gerhard Brant war in Basel Mitglied eines Konzilsausschusses zur Verhandlung mit kölnischen Hussiten. Auch ein weiterer Heidelberger, Otto de Lapide, war an den Verhandlungen mit dem gemäßigten Flügel der Hussiten beteiligt. Von, Johannes von Frankfurt, Nikolaus Magni de Jawor, den Brüdern Reinbold und Job Vener sowie allen weiteren an den Konzilien und Inquisitionsprozessen Beteiligten hören wir dergleichen nicht.

\section{HEIKE HAWICKS}

\section{HEIDELBERG A HUSITISMUS: PROFESOŘI JAKO VYSLANCI, AUTOŘI DOBROZDÁNÍ A INKVIZITOŘI}

\section{RESUMÉ}

Ústřední postavou všech protihusitských aktivit v okruhu kurfiřta Ludvíka III. byl Jan z Frankfurtu. Účastnil se rozhodujícím způsobem všech procesů s kacírii, v polním táboře koncipoval dobrozdání proti husitům a byl zastoupen v delegaci do Kostnice. Neobjevuje se na žádném dalším koncilu, ale vyvíjel horlivou aktivitu jako inkvizitor. Oproti tomu Mikuláš Magni z Javora, Gerhard Brant a zvláště Konrád Koler ze Soestu se koncilủ účastnili. Posledně jmenovaný byl činný na všech koncilech, a v Basileji (jako řezenský biskup) byl dokonce jedním ze tří předsedů komise pro víru, která vedla jednání s husity. Právě on doprovázel jejich delegaci r. 1432 do Basileje. Jeho někdejš́ heidelberský kolega Gerhard Brant byl v Basileji členem koncilního výboru k jednání s kolínskými husity. Také další heidelberský profesor, Otto de Lapide se účastnil jednání s umírněným kř́ílem husitů. O Janu z Frankfurtu, Mikuláši z Javora, bratrech Reinholdovi a Jobovi Venerech a všech ostatních účastnících koncilů a inkvizičních procesů nic takového neslyšíme.

Dr. Heike Hawicks

Ruprecht-Karls-University Heidelberg

heike.hawicks@zegk.uni-heidelberg.de 